HORTSCIENCE 27(10):1133-1134. 1992.

\title{
Scanning Electron Microscopy of Floral Development in Freesias
}

\author{
Ludwika Kawa ${ }^{1}$ \\ Research Institute of Pomology and Floriculture, 96-100 Skierniewice, \\ Poland
}

\author{
August A. De Hertogh ${ }^{2}$ \\ Department of Horticultural Science, North Carolina State University, \\ Raleigh, NC 27695-7609
}

Additional index words. shoot apical meristem, flower initiation and organogenesis

\begin{abstract}
Shoot apical meristems of Freesia xhybrida Klatt 'Rossini' reached the reproductive state after 3 weeks of precooling at 9C. Meristems isolated after 6 and 7 weeks of precooling showed the development of the initial four florets of the inflorescence.
\end{abstract}

The developmental cycle of Freesia cultivars is controlled primarily by temperature (De Lint, 1969; Gilbertson-Ferriss, 1985; Smith and Danks, 1985; Vijverberg, 1982). After being harvested, the corms require $>12$ weeks of storage at $30 \mathrm{C}$ to satisfy internal dormancy. They can subsequently be forced as cut flowers or potted plants.

Currently, freesias being forced as potted plants require 6 to 7 weeks of corm precooling (De Hertogh, 1989). Therefore, this study was undertaken to follow the morphology of floral initiation and development in Freesia during this precooling period using the scanning electron microscope (SEM). Floral development of isolated apical meristems was illustrated with light microscopy by Vijverberg (1982). He also provided drawings of meristems. This is the only report illustrating the floral morphology of Freesia, but the techniques used did not provide cellular details.

The inflorescence of Freesia cultivars is a racemose spike with a central axis on which sessile flowers are borne. Each floret has membranous or dark green bracts, six tepals,

Received for publication 7 Oct. 1991. Accepted for publication 11 May 1992. We acknowledge the donation of the corms by Penning Freesia B.V. Honselersdijk. The Netherlands, and the financial support of The Dutch Bulb Exporters Assn., Hillenom, The Netherlands. We thank Valerie Knowlton and Gwendolyn Pemberton for their assistance with the SEM procedures. The use of trade names in this publication does not imply endorsement by the North Carolina Agricultural Research Service of the products named, nor criticism of similar ones not mentioned. The cost of publishing this paper was defrayed in part by the payment of page charges. Under postal regulations, this paper therefore must be hereby marked advertisement solely to indicate this fact.

'Researcher.

'Professor. six stamens, and a bifid branched style. The flowering stalk may be branched.

Corms of Freesia 'Rossini' were grown in The Netherlands, stored at $30 \mathrm{C}$ for at least 3 months, and shipped by air on 29 Sept. 1990 to Raleigh, N.C. After arrival on 4 Oct., corms were stored at $17 \mathrm{C}$, then placed at $9 \mathrm{C}$ on 12 Oct. Shoot apices were isolated on this date and at 7-day intervals until 30 Nov. 1990. Meristems were isolated with the use of binocular microscope. The meristems were kept moist at all times by holding them under distilled water during isolation. When necessary, leaf primordia were carefully removed to expose the meristematic mantel. After being isolated, the meristems were fixed in FAA (5 formalin : 5 glacial acetic acid : 45 ethanol : 45 water) for a minimum of 24 $\mathrm{h}$ before being dehydrated in a graded ethanol series $(30 \%, 50 \%, 70 \%, 95 \%, 100 \%, 100 \%$, $100 \%$ ). Directly after the $100 \%$ ethanol step, the meristems were critical-point-dried using liquid CO, in a Samdri PVT-3B (Tousimis Research Corp., Rockville, Md.). They were subsequently mounted on SEM stubs with double stick tape (adhesive dots) and sputtercoated with $60 \mathrm{~nm}$ gold-palladium. They were viewed and photographed with a Philips 505 T SEM (Philips, Eindhoven, The Netherlands) using a $15-\mathrm{kV}$ accelerating potential.

On arrival, all shoot apical meristems were vegetative and had a single leaf primordium (Fig. 1A). The diameter of the meristems was very small, making them difficult to isolate. Vijverberg (1982) indicated that freesia meristems have a diameter $<1 \mathrm{~mm}$. The apical meristem became reproductive after 3 weeks of dry storage at 9C (precooling). The first flower primordium was clearly visible after 4 weeks (Fig. 1B). These observations confirmed those of Vijverberg (1982), who stored corms initially for 24 weeks at 30C, and then at $14 \mathrm{C}$. With continued corm storage at $9 \mathrm{C}$, floret primordia were visible after 

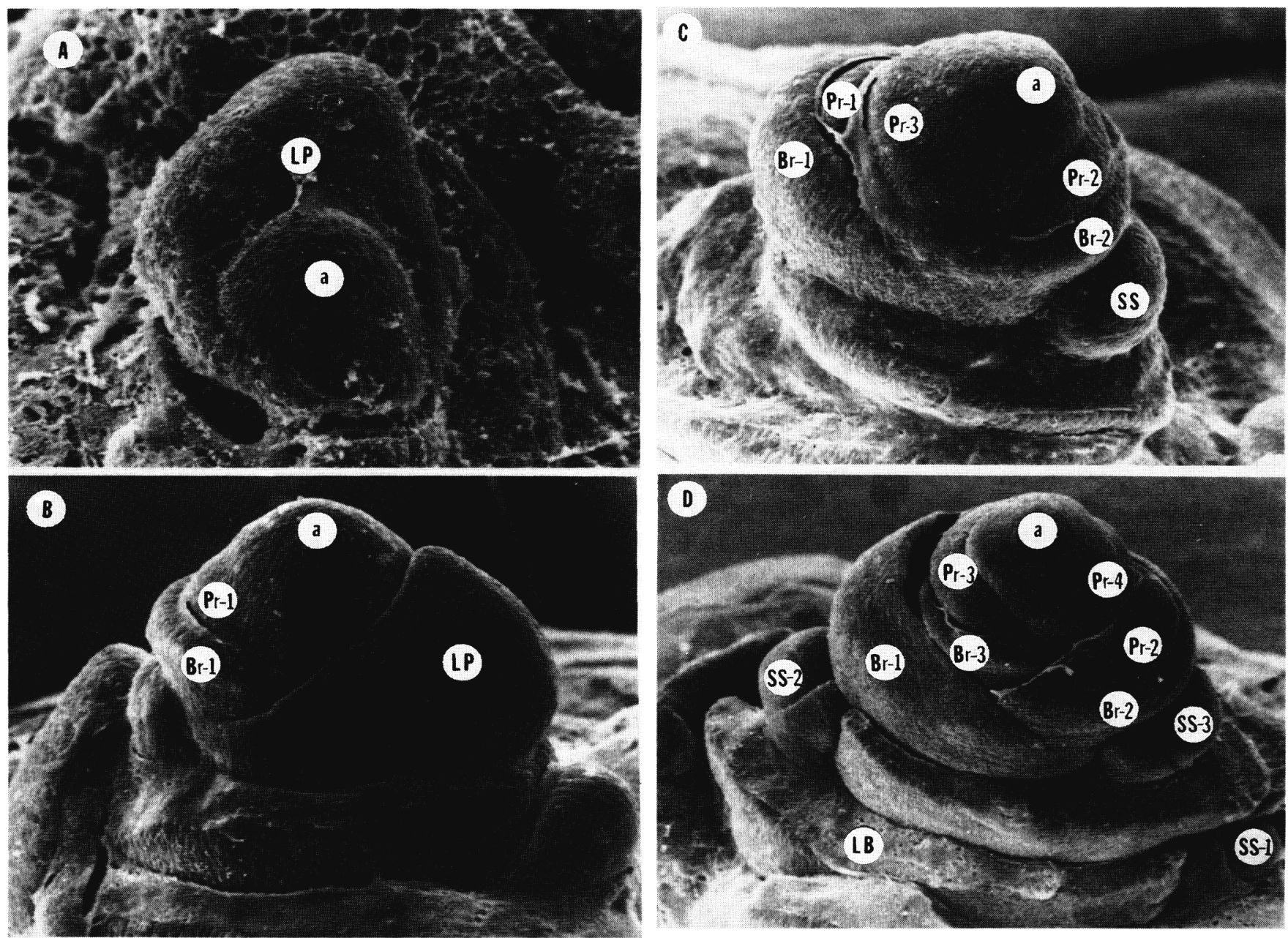

Fig. 1. Scanning electron photomicrographs of shoot meristem development of Freesia 'Rossini'. (A) On arrival, 0 weeks at $9 \mathrm{C}, \times 244 . \mathrm{a}=\mathrm{Vegetative}$ shoot apex; LP = leaf primordium. (B) After 4 weeks at 9C, $\times 127$. a $=$ Reproductive shoot apex; Pr-1 = growing primordium of first flower; Br-1 $=$ first flower bearing bract primordium; $\mathrm{LP}=$ leaf primordium. (C) After 6 weeks at $9 \mathrm{C}, \times 133 . \mathrm{a}=$ Shoot apical meristem; $\operatorname{Pr}-1,-2,-3=$ primordia of first, second, and third flowers; Br-1, $-2=$ bracts subtending flowers; SS $=$ secondary shoot. (D) After 7 weeks at $9 \mathrm{C}, \times 83 . \mathrm{a}=$ Apical meristem; Pr-I, $-2,-3,-4=$ primordia of second, third, and fourth flowers. The primordium of first flower is not visible. $\mathrm{Br}-1,-2,-3=$ bracts subtending flowers; SS-1, $-2,-3=$ secondary shoots; LB = scar of removed leaf base.

6 weeks (Fig. $1 \mathrm{C}$ and D); the primordia of first and second flowers were distinctly visible (Fig. 1C) and the third flower primordium was forming. The arrangement was distichous. After 7 weeks, primordia of the first, second, third, and fourth flowers had been initiated (Fig. 1D). In addition, three lateral stem apices were present (Fig. 1D).

Since most Freesia cultivars have inflorescences with up to 12 or 13 florets (Smith and Danks, 1985; Vijverberg, 1982), floral development obviously continues for several weeks after planting. Under most commercial forcing conditons, the corms are planted after 7 weeks of precooling (De Her- togh, 1989). Thus, development of the inflorescence will be affected for several weeks after planting, and the environmental conditions in the greenhouse are important. To observe floral development after 7 weeks of storage at 9C, 64 corms of 'Rossini' (eight corms per 1.6-liter azalea pot) were planted in Sunshine Mix No. 4 on 3 Dec. 1990 and forced at 16 to $18 \mathrm{C}$. The average number of florets produced per inflorescence was 10 and the average number of shoots per corm was 2.6.

\section{Literature Cited}

De Hertogh, A.A. 1989. Holland bulb forcer's guide. 4th ed. Intl. Flower Bulb Centre, Hillegom, The Netherlands.

De Lint, P.J.A.L. 1969. Flowering in Freesia: Temperature and corms. Acta Hort. 14:125-131.

Gilbertson-Ferriss, T.L. 1985. Freesia $\times$ hybrida, p. 34-37. In: A. Halevy (ed.). Handbook of flowering. vol. III. CRC, Boca Raton, Fla.

Smith, D. and P.N. Danks. 1985. Freesias. 2nd ed. Grower Guide no. 1. Grower Books, London.

Vijverberg, A.J. (chairman). 1982. Teelt van Freesia. Proefstation Voor Tuinbouw Onder Glas Te Naaldwijk, Proefstation Voor De Bloemisterij Te Aalsmeer, Consulentschappen Voor De Tuinbouw. Bloementeeltinformatie Nr. 5. 